ORAL FORMULAIC LANGUAGE IN THE BIBLICAL PSALMS 


\section{NEAR AND MIDDLE EAST SERIES}

1. The Mosaic Tradition. By F. V. WinnetT

2. Safaitic Inscriptions from fordan. By F. V. WiNNETT

3. History and Chronology of the Eighteenth Dynasty of Egypt: Seven Studies. By Donald B. REDFord

4. Oral Formulaic Language in the Biblical Psalms. By RoBerT C. Culley

5. Fewish and Mandaean Incantation Bowls in the Royal Ontario Museum. By W. S. McCullough 


\title{
Oral Formulaic
}

\author{
Language \\ in the \\ Biblical Psalms
}

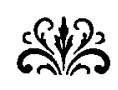

ROBERT C. CULLEY

UNIVERSITY OF TORONTO PRESS 
(C) UNIVERSITY OF TORONTO PRESS 1967

PRINTED IN BELGIUM 
To My Mother and Father 
This page intentionally left blank 